\title{
Marketing of Milk in Satara District of Maharashtra
}

\author{
S.L. Jadhav ${ }^{1}$, K.V. Deshmukh ${ }^{2}$ and R.D. Shelke ${ }^{3^{*}}$ \\ ${ }^{1}$ College of Agriculture, Latur, India \\ ${ }^{2}$ Department of Agricultural Economics, COA, Parbhani, India \\ ${ }^{3}$ Department of Agricultural Economics, COA, Latur, India \\ *Corresponding author
}

\begin{tabular}{|l|}
\hline \multicolumn{1}{|l|}{} \\
\hline K e y w o r d s \\
Marketing cost, \\
Marketing margin, \\
Price spread, \\
Producer share, \\
Marketing channel \\
\hline Article Info \\
\hline $\begin{array}{l}\text { Accepted: } \\
\text { 20 October } 2020 \\
\text { Available Online: } \\
\text { 10 November } 2020\end{array}$ \\
\hline
\end{tabular}

\section{A B S T R A C T}

The study marketing of milk in Satara district of Maharashtra on the data collected in the year 2018-19. Tabular analysis was used for the calculating the marketing cost, marketing margin and price spread. The respondent farmer marketing of milk through different channels. Channel I - Producer to cooperative dairy, Channel II - Producer to private dairy, Channel III Producer to consumer. The producer share in consumer rupee per cent was highest for channel III i.e. 95.98, channel I 64.87, channel II 62.85. Producer share in consumer rupee was highest when milk directly sold to the consumer.

\section{Introduction}

Milk being the most perishable commodity, required a quick and efficient marketing system. An efficient marketing system is which minimizes the cost of marketing and to ensure the largest share in consumer's price to the producers. The consumers should be provided with quality produce at a reasonable price. Bulk of business is transacted through traditional channels. The private traders exploit both the producers and the consumers. Dairy cooperatives have been considered as one of the most important measures to improve the production and ensure efficient marketing. The marketing system links the milk producers to the distant urban areas. Its efficient marketing system is essential to minimize the marketing cost and get higher returns. The present study was to workout price spread and producer's share in consumer rupees in different marketing channel of milk. The study shows the existing marketing channel and price spread for cow milk through different marketing channel.

\section{Materials and Methods}

The present study was conducted in the Satara district of Maharashtra state during the year of 2018-19. 


\section{Sampling plan}

The study was based on the primary as well as secondary data. For the collection of data multistage sampling technique was adopted. The Satara district was purposively selected because it is known for higher milk production in the Western Maharashtra region. In the Satara district two tehsils namely Phaltan and Karad was selected as the cross-breed cows are more concentrated in these two tehsils. From each tehsils three villages was selected randomly. Vasantgad, Sakurdi and Kodoli villages from karad tehsil and Somanthali, Vidni, Sonawadi villages from Phaltan tehsils. The list of farmers having crossbred cow was prepared from six villages. 15 farmers from each village will be selected purposively on the basis of farmers having number of crossbred cow. The respondents are categorised into three categories on the basis of herd size viz Small farmer (1-2 crossbred cow), medium farmer (3-5 crossbred cow) and large farmer 6-10). Thus, 90 Farmers having cross-breed cow was selected.

\section{Results and Discussion}

The crossbreed cow milk was produced on respondent farmers was marketed through three different channels

Channel I: Producer to cooperative dairy

Channel II: Producer to private dairy

Channel III: Producer to consumer

\section{Production and marketing of milk}

The quantities of milk produced from crossbreed cow milk on respondent farmer was sold through different channels. The total quantities of milk sold through different channels was 101627.36 lit. Out of which the milk sold through channel I - producer to cooperative dairy was 34346.03 which was
$33.80 \%$ to the total milk sold through different channels. The milk sold through channel II - producer to private dairy was 66266.18 lit which was $65.20 \%$. The milk sold through channel III - producer to consumer was 1015.15 lit which was $1.00 \%$ to the milk sold through different channels.

In the channel I producer to cooperative dairy the milk sell from small, medium and large size group of farmers was 5237.33 lit, 13473.22 lit and 15635.48 lit respectively. The average rate obtained from channel I to the farmers was 29.76₹. In the channel II producer to private dairy the average rate obtained to the farmer was $28.74 ₹$. In the channel II the total milk sold from small, medium and large size group of farmers was 5548.33 lit, 16616.56lit and 44101.29 lit respectively. In the channel III producer to consumer the average rate obtained to the producer was 31.34 . In the channel III the total milk sold from small, medium size group of farmer was 674.51 lit and 340.64lit respectively.

From the three different marketing channels the highest quantities of milk sold through channel II Producer to Private Dairy was 66266.18 lit which accounted $65.20 \%$ to the total milk sold from different marketing channels.

Price spread of cross-bred cow milk for different Marketing channels of milk

Price spread means the difference between price paid and received by a specific marketing agency such as consumer, dairy etc.in the table 1 the price spread of crossbred cow milk through the different marketing channels was shown.

In the table 2 the respondent famer selling of milk was done by the different milk marketing channels. 
Channel I: Producer $\rightarrow$ Co-operative dairy

Channel II: Producer $\rightarrow$ Private dairy

Channel III: Producer $\rightarrow$ Consumer

For Channel I the selling Price was the 28.47₹, for the Channel II 29.76₹. For the Channel III 31.34₹, for per liter of milk obtained from the cross bred cow.

Marketing cost of producers was different for different marketing Channels which is used for marketing. For channel I it was $1.37 ₹$, for Channel II 1.53₹, for Channel III 1.20₹, per liter of milk marketed through different channels

For Channel III marketing of milk was directly producer to consumer, therefore there was no any middleman. Marketing cost was incurred by middleman was $2.35 ₹$ ₹ $2.75 ₹$ per liter of milk for the Channel I and II respectively.

The marketing margin for middleman was $1.35 ₹$ and 2.00 ₹per litre of milk for the Channel I and channel II respectively. It is observed that marketing cost and marketing margin of middleman was more for the channel II than the Channel I. For channel I and channel II middleman sold milk to the wholesaler at $32.17 ₹$ per liter and $34.51 ₹$ it is wholesaler price.in the channel I and channel II wholesaler required marketing cost was ₹5.60 and ₹ 6.00respectively. In channel I and II Wholesaler sold it to consumer with $41.77 ₹$ and $44.91 ₹$ per liter of milk. In the channel I and channel II Middleman earned margin $₹ 4.00$ and ₹ 4.40per liter of milk. For Channel I and II wholesaler purchasing price was $₹ 28.47$ and ₹ 29.76 per liter of milk. From the table 2 it is observed that wholesaler margin and marginal cost was higher for channel II.

From the table 2 it can be observed that the net price received to producers were 64.87, 62.85 and 95.98 per cent of the total price paid by consumer to the channel I, II and III respectively. The producer's share in consumer rupees was highest to that farmers, who have sold their milk to the channel III than the channel I, and channel II respectively.

Table.1 Channel wise marketing of milk

\begin{tabular}{|l|l|l|l|l|l|l|l|}
\hline Sr.No & $\begin{array}{l}\text { Name of } \\
\text { Channel }\end{array}$ & Rate & Small & Medium & Large & Total & $\begin{array}{l}\text { Per cent } \\
\text { to total }\end{array}$ \\
\hline 1. & $\begin{array}{l}\text { Producer to } \\
\text { Co- operative } \\
\text { dairy }\end{array}$ & 29.76 & 5237.33 & 13473.22 & 15635.48 & $\mathbf{3 4 3 4 6 . 0 3}$ & 33.80 \\
\hline 2. & $\begin{array}{l}\text { Producer to } \\
\text { Private Dairy }\end{array}$ & 28.47 & 5548.33 & 16616.56 & 44101.29 & 66266.18 & 65.20 \\
\hline 3. & $\begin{array}{l}\text { Producer to } \\
\text { Consumer }\end{array}$ & 31.34 & 674.51 & 340.64 & - & 1015.15 & 1.00 \\
\hline & & & & & & 101627.36 & 100.00 \\
\hline
\end{tabular}

(Lit/Channel) 
Table.2 Price spread of cross-bred cow milk for different marketing channels of milk (₹/lit.)

\begin{tabular}{|c|l|c|c|c|}
\hline Sr.No. & \multicolumn{1}{|c|}{ Particulars } & I & II & III \\
\hline $\mathbf{1}$ & Producer sale price & 28.47 & 29.76 & 31.34 \\
\hline $\mathbf{2}$ & Marketing cost of producer & 1.37 & 1.53 & 1.20 \\
\hline $\mathbf{3}$ & Net price received by producer & 27.10 & 28.23 & 30.14 \\
\hline $\mathbf{4}$ & Purchase price of middleman & 28.47 & 29.76 & - \\
\hline $\mathbf{5}$ & $\begin{array}{l}\text { Marketing cost incurred by } \\
\text { middle man }\end{array}$ & 2.35 & 2.75 & - \\
\hline $\mathbf{6}$ & Marketing margin & 1.35 & 2.00 & - \\
\hline $\mathbf{7}$ & Sale price of middleman & 32.17 & 34.51 & - \\
\hline $\mathbf{8}$ & Wholesaler price & 32.17 & 34.51 & - \\
\hline $\mathbf{9}$ & Wholesaler margin cost & 5.60 & 6.00 & - \\
\hline $\mathbf{1 0}$ & Wholesaler margin & 4.00 & 4.40 & - \\
\hline $\mathbf{1 1}$ & Consumer price & 41.77 & 44.91 & 31.40 \\
\hline $\mathbf{1 3}$ & Producers share in consumer $(₹)$ & 64.87 & 62.85 & 95.98 \\
\hline
\end{tabular}

In the table 2 it is observed that channel III was most profitable among the other two channels at the producer's as well as consumer's level. Therefore it was most profitable channels for the respondents farmer as well as to the consumer.

\section{References}

Sonawane, T.S., Kolekar, P.L. and Nimbalkar, S.S. (2017). Marketing of milk in Pune district of Maharashtra. International Research Journal of Agricultural Economics \& Statistics, 8 (1): 186-
189.

Sujatha, R. V., Suseela, T. and Suseela, K. (2015). Milk Marketing in Cooperative sector and Private sector in Andhra Pradesh, India: A Comparative study. International Journal of Scientific and Research Publications, 5(12): 401-406.

Wani, S.A. and M. H. Wani (2010). Marketing of milk in various Agroclimatic zones of Jammu and Kashmir. Agricultural Economics Research Review, 23 (1): 83-90.

\section{How to cite this article:}

Jadhav, S.L., K.V. Deshmukh and Shelke, R.D. 2020. Marketing of Milk in Satara District of Maharashtra. Int.J.Curr.Microbiol.App.Sci. 9(11): 2634-2637.

doi: https://doi.org/10.20546/ijcmas.2020.911.319 